\title{
Global Perspectives
}

Bruno Lopes dos Santos-

Lobato, MD, MSc

Octávio Marques Pontes-

Neto, MD, PhD

Correspondence to

Dr. Lopes dos Santos-Lobato: bruls4@usp.br

\section{SHORTAGE OF NEUROLOGISTS IN THE BRAZILIAN AMAZON}

Neurologic disorders, including headache, epilepsy, and cerebrovascular disease, are common sources of medical consults and hospital admissions. ${ }^{1}$ Conditions such as stroke, the world's second leading cause of death, are medical emergencies that demand fast and efficient actions to reduce mortality and disability rates. These 2 points highlight the growing importance of neurology health care in developing countries.

Brazil is an emerging country with rising economic development over the last 20 years and with the world's 7 th wealthiest economy. However, Brazil's ranking on the United Nations' Human Development Index (79th position, based on 2014 data) is paradoxically low in comparison to its economic status. Brazil's continental dimensions amplify the inequalities among its regions, and the Amazon is the least developed area of the country. In this article, we discuss some of the reasons for the paucity of neurologists within the Brazilian Amazon. Furthermore, we discuss possible new strategies to ease those public health inequalities in the near future.

According to the Brazilian Institute of Geography and Statistics, the country's population was estimated to be $202,768,562$ in 2014 ; a total of $17,231,027(8.4 \%)$ of these inhabitants lived in the Brazilian Amazon, distributed over 3,869,637 $\mathrm{km}^{2}$, which corresponds to $45 \%$ of the national territory, the lowest demographic density in $\mathrm{Brazil}^{2}$ (figure). The Brazilian Amazon has a marked and diffuse poverty, with a per capita household income of about $\$ 190$ USD, half of the per capita income of the Southeast region, the most developed area of the country.

Brazil has 1.66 neurologists per 100,000 inhabitants, ${ }^{3}$ greater than the minimum of 1 neurologist per 100,000 inhabitants recommended by the WHO and greater than the average found on the American continent. ${ }^{3}$ On the other hand, states that compose the Brazilian Amazon have an average of 0.5 neurologists per 100,000 inhabitants, a ratio comparable to most Arab countries and better than
sub-Saharan Africa. Brazilian regional inequality also is reflected in the distribution of specialists: in the Southeast region, the ratio is 2 neurologists per 100,000 inhabitants. $^{3}$

The scarcity of physicians in the Brazilian Amazon is aggravated by a lack of transport infrastructure, which limits the free movement of health professionals through the Amazonian hinterlands and vast extensions of the rainforest. The majority of neurologists in the Amazon are concentrated in the states' capitals, and neurologic care for hinterland inhabitants is extremely rare, forcing these populations (including riverbank and indigenous people) to travel great distances and wait several months for a neurologic consultation.

The number of neurologists can be increased through the training of new specialists. In Brazil, there are 76 neurology residency programs, which offered 233 positions in 2014; only 3 positions were offered in hospitals located in the Brazilian Amazon. A recent inquiry showed that physicians from other regions of Brazil have little interest in moving to the Amazon, and the majority of medical doctors graduated from Amazonian universities do not come back after their specialty training in other regions. ${ }^{3}$ Furthermore, physicians living in the Amazon have the shortest clinical medical activity time in Brazil (about 25 years in a lifetime), probably due to migration to other regions or other countries. ${ }^{3}$

Considering the low number of neurologists in the Brazilian Amazon, the scarce regional training of new neurologists, the low migration of these specialists from other regions, and the lack of interest in existing neurologists to live in the Amazonian hinterland cities, neurologic care in the Brazilian Amazon is unlikely to improve over the next few years. A significant change in public health policies directed at enhancing the specialty of neurology within the Brazilian Amazon is imperative in this setting.

Experiences from other developing countries can be used as a model for the Brazilian Amazon neurologic care problem. In Honduras, a partnership between a local university and the World Federation of Neurology has increased the training of new 


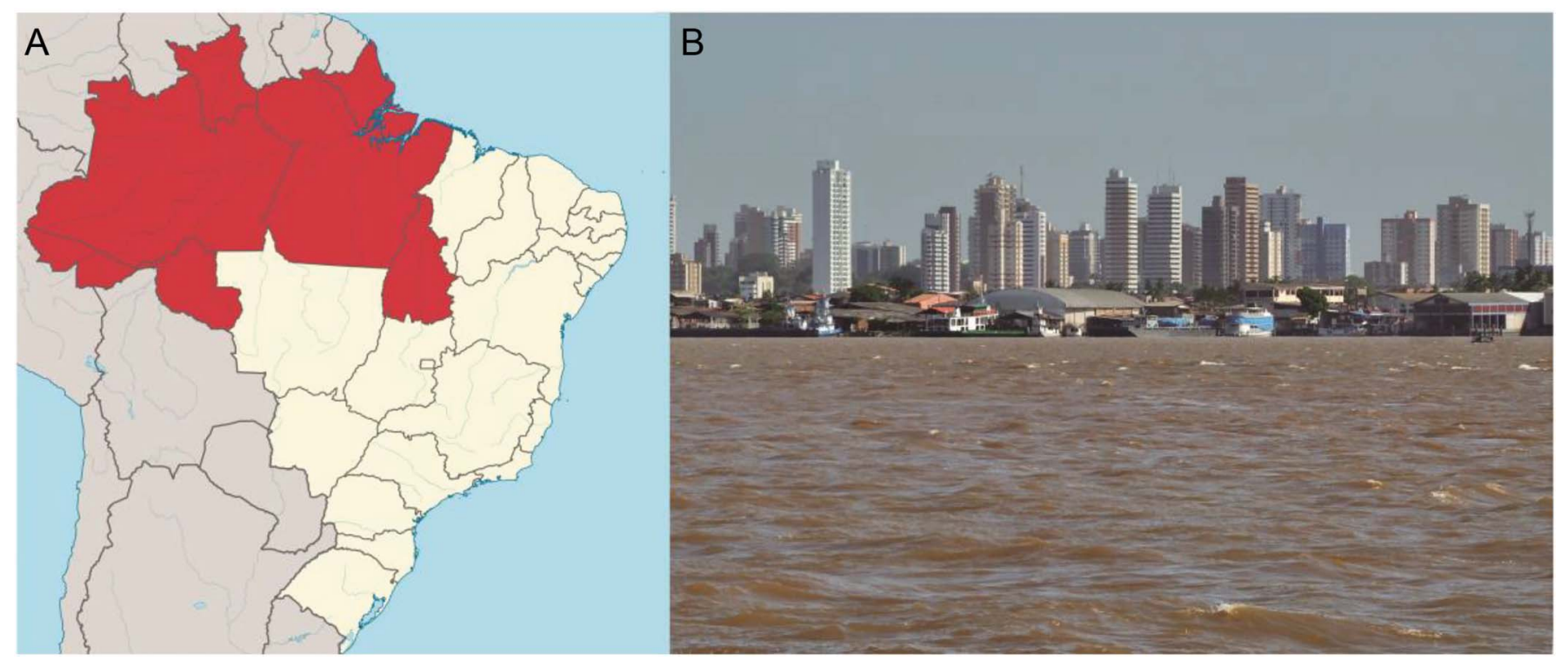

(A) Map of Brazil, with red area indicating Brazilian Amazon (available at http://upload.wikimedia.org/wikipedia/commons/thumb/5/5c/North_Region_in_Brazil. svg/2000px-North_Region_in_Brazil.svg.png). (B) City of Belém do Pará, one of the major cities of Brazilian Amazon (available at http://upload.wikimedia.org/ wikipedia/commons/d/d9/Bel\%C3\%A9m_from_SE_01.jpg).

neurologists, easing the great deficit of specialists in this country. ${ }^{4}$ In the Ecuadorian Amazon, missions organized by local and foreign health professionals provide neurologic consultations for an underserved rural population. ${ }^{5}$

Another strategy that could also be tested and implemented in the Amazon is telemedicine. Developed countries such as Canada, Portugal, the Netherlands, and the United States have successfully used telemedicine to provide neurologic care to low population density regions. In Brazil, telemedicine was officially authorized by the Federal Medical Council in 2002. This ancillary channel of clinical care is well-suited to the Brazilian Amazon, helping to offer neurologic consultations in areas with extremely low population density and difficult access.

As with other deprived areas of the country, the Amazon urgently needs additional public resources and investments to improve its health care facilities. It is also critical to develop residency programs in the region and to improve the training of new physicians graduated from Amazonian universities every year. Local universities must assume responsibility over gaps in public health care and neurology should be acknowledged and included within these challenges. In this context, partnerships with private institutions and international organizations such as the World Federation of Neurology are essential to expand neurologic care to this underserved region with a long history of governmental neglect.

\section{AUTHOR CONTRIBUTIONS}

Bruno Lopes dos Santos-Lobato: conceptualization, drafting, and revising. Octávio Marques Pontes-Neto: drafting and revising.

\section{STUDY FUNDING}

No targeted funding reported.

\section{DISCLOSURE}

The authors reports no disclosures relevant to the manuscript. Go to Neurology.org for full disclosures.

\section{REFERENCES}

1. World Health Organization. Atlas: Country Resources for Neurological Disorders. Geneva: WHO; 2004.

2. Population estimates in Brazil and federal units on July 1, 2014. In: Brazilian Institute of Geography and Statistics [online]. Available at: ftp://ftp.ibge.gov.br/Estimativas_de_ Populacao/Estimativas_2013/populacoes_estimativas_BR_UF_ TCU_31_10_2013.pdf. Accessed January 13, 2015.

3. São Paulo State Regional Council of Medicine. Medical Demography in Brazil. Vol 2. São Paulo, Brazil: 2013. Available at: http://portal.cfm.org.br/images/stories/pdf/ demografiamedicanobrasil_vol2.pdf. Accessed July 25, 2014.

4. Medina MT, Munsat T, Portera-Sanchez A, et al. Developing a neurology training program in Honduras: a joint project of neurologists in Honduras and the World Federation of Neurology. J Neurol Sci 2007;253:7-17.

5. Laccheo I, Espinosa PS. International issues: neurology mission in the Ecuadorian Amazon rainforest. Neurology 2012; 78:e60-e62. 


\title{
Neurology
}

\author{
Shortage of neurologists in the Brazilian Amazon \\ Bruno Lopes dos Santos-Lobato and Octávio Marques Pontes-Neto \\ Neurology 2015;85;1710-1711 \\ DOI 10.1212/WNL.0000000000002103
}

This information is current as of November 9, 2015

Updated Information \&

Services

References

Subspecialty Collections

Permissions \& Licensing

Reprints including high resolution figures, can be found at: http://n.neurology.org/content/85/19/1710.full

This article cites 2 articles, 1 of which you can access for free at: http://n.neurology.org/content/85/19/1710.full\#ref-list-1

This article, along with others on similar topics, appears in the following collection(s):

Health care reform

http://n.neurology.org/cgi/collection/health_care_reform

Medical care

http://n.neurology.org/cgi/collection/medical_care

Methods of education

http://n.neurology.org/cgi/collection/methods_of_education

Models of care

http://n.neurology.org/cgi/collection/models_of_care

Other Education

http://n.neurology.org/cgi/collection/other_education

Underserved populations

http://n.neurology.org/cgi/collection/underserved_populations

Information about reproducing this article in parts (figures,tables) or in its entirety can be found online at:

http://www.neurology.org/about/about_the_journal\#permissions

Information about ordering reprints can be found online:

http://n.neurology.org/subscribers/advertise

Neurology ${ }^{\circledR}$ is the official journal of the American Academy of Neurology. Published continuously since 1951, it is now a weekly with 48 issues per year. Copyright @ 2015 American Academy of Neurology. All rights reserved. Print ISSN: 0028-3878. Online ISSN: 1526-632X.

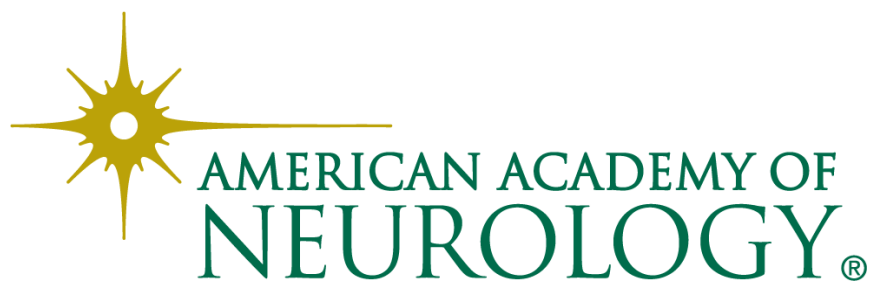

